\title{
家畜血清蛋白に関する汇紙電気泳動学的研究
}

\author{
第 $V$ 報の 1 犬糸状虫症に抢沙る血清蛋白像，とくに血清蛋白・ \\ 複合蛋白抒よび腹水蛋白像について
}

友田勇*

(昭和 37 年 5 月 8 日受付)

犬系状虫 Dirofilaria immitis はわが国の犬に高濃度 に寄生し, その病害は著明である. 本症は一般に循環障 害と希血症を主症状とし, 榃血はとくに概血肝より肝硬 変へと進行する一連の肝機能障害と腹水の原因となると されている14).

一方，血清蛋白は病的状態では著るしい变動を呈する ことが知られ，とくに Tiselius 電気泳動法が臨床面に 応用されて以来簡便な沪紙電気泳動法の急速な普及とと も病的血清蛋白の動態関する臨床的意義は次第に明 確となった6,7,9,18,21, 22). 糸状虫症に扮いても albumin (以下 alb) の減少と $r$-globulin (以下 glob) の增加 が認められて敊り 13,16), 就中大系状虫症では著るしい glob の増大が観察されている19). しかしながら, 諸種 疾患時の血清蛋白像は多くの場合非特異的であって, そ れ自体だけでは臨床診断的価值は必らずしも高いと注い えず，したがって臨床上診断ならびに治療面への資料と して役立たしめるためには, 必然的に病的状態と血清蛋 白との関連についての多数の臨床的事実の集積によらね ばならない。

そこで, 家畜血清蛋白に関する沪紙電気泳動学的研究 の一環として, 犬系状虫症における血清蛋白の動態を観 察し，その臨床的意義について検討を加えたので報告す る.

\section{I 研究材料和よび方法}

1. 供試犬 末梢血液中に microfilaria（以下 mf）の 存在を確認した犬 132 例について観察した.

いずれも腸内寄生虫卵会性も乙くは駆虫後少なくとも 3 週以上を経過し, 乙かも犬系状虫感染以外によると思 われる症状の続併発を認めない東大家畜病院の外来患犬 であって，品種・性別・飼養条件などは考虑していな い。な和，末梢血液中 $\mathrm{mf}$ 陰性かつ他の寄生虫感染が認 められない臨床上健康と又られる成熟雑種犬多数例の平 均值をもって対照値として取扱うこととし，58例を使用 した.

2. 血清総蛋白量・血清蛋白执よび血清複合蛋白各分 画の測定 血清総蛋白量は日立蛋白計を使用し, 血清蛋

* 東京大学農学部
白ならびに血清複合蛋白分画は小林式沪紙電気泳動装置 により扮拈む放電気泳動学会標準操作法試案 25$)$ 特よび五 味淵の法5) に準じて行なった。汇紙は東洋汇紙 No.51A を使用し, $0.5 \mathrm{~mA} / \mathrm{cm}$ で $\mathrm{BPB}$ 標識 $\mathrm{alb}$ が原点より 7 $\sim 8 \mathrm{~cm}$ 移動するまで通電し, $110^{\circ} \mathrm{C} 20$ 分乾燥後, 蛋白は Amidoschwarz 10B，リポ蛋白は Sudan Black B, 糖蛋 白は過沃素酸一Schiff 試薬で染色し, Densitometer に より測定した。

\section{3. 腹水蛋白}

腹水貯溜犬 8 例について同時に腹水蛋白像を観察する とともに, 癌性腹膜炎犬 3 例の腹水蛋白像と比較した. 腹水採取には減菌注射器を使用し, 腹部穿刺により採取 して直ちに遠心し，上清について血清の場合と全く同じ 方法により泳動分析を行なった。なお，蛋白濃度の低い 腹水の際はカーボワックス法2)にて濃縮した。

\section{1. 血清蛋白像}

\section{II 成 績}

犬系状虫寄生犬の血清蛋白像を観察するに当って, 臨 床所見から便宜上未発症犬と発症犬とに大別し, さらに 発症犬は肝硬変を呈し腹水貯溜・呼吸困難 - 心機能障 害・希血症なぞの諸症状を発したものを重症, これに比 して症状軽度で重症型移行する以前のものと考兄られ る状態のものを軽症として取扱い，各症群の血清蛋白像 を検討することとした。

すなわち, 犬系状虫寄生犬の血清蛋白所見は, 表 1 , 2 および図 1 亿示すように対照 $\mathrm{mf}$ 陰性犬の血清蛋白像 に比較して著変が認められ, 一般㳂蛋白量の增加, alb 分屑の減少之 $\beta-, \gamma$-glob 分尿の增加, したがって $\mathrm{A} / \mathrm{G}$ 比の著るしい低下を呈した，症状の增覀にともなっ て增大する傾向があり, 重症例では肝硬変を反映して著 るしい $\beta-, \gamma$-glob 分屑の増大と alb 分屑の減少を認め た。しかしながら，障害の程度・年令・経病期間の長 短, あるいは宿主の抵抗など諸種の要因に基く個体差が 著るしく認められ, 就中未発症犬に顕著であった.

$\mathrm{mf}$ 陽性犬の年令と血清蛋白像との 関係を検討した結 果, 血清蛋白像はむしろ障害・症状の程度を反映して一 般に年令との間に明確な関係を示さず, 未発症犬におい て年令の增加とともに alb 濃度比の低下, $\beta-, \gamma-$ glob 
濃度比の増加する傾向が若干認められるに過ぎない。

も全く年令との場合と同じ所見が得られ，症状に関係な

また，末梢血中 $\mathrm{mf}$ 数と血清蛋白像との関係について

く一定の傾向は認め難かった。

表 1 末梢血液中 $\mathrm{mf}$ 陽性犬血清蛋白像（症例平均）

\begin{tabular}{|c|c|c|c|c|c|c|c|c|c|}
\hline ; & 例數 & & 総掻白屋 & $\begin{array}{c}\text { AIn } \\
\text { AIbumin }\end{array}$ & $\begin{array}{l}\text { 白 } \\
a_{1}\end{array}$ & 分 & $\begin{array}{c}\text { 層 侐 } \\
\text { Bobulin } \\
B\end{array}$ & $\gamma$ & $A / Q^{\circ}$ \\
\hline \multirow{2}{*}{ 血中m.f. 陵性犬゙ } & \multirow{2}{*}{47} & \% & & 48.1 & 7.5 & 8.6 & 22.3 & 13.5 & 0.94 \\
\hline & & $\mathrm{B} / \mathrm{d} \mathrm{I}$ & 6.8 & 3.27 & 0.51 & 0.58 & 1.52 & 0.92 & \\
\hline \multirow{2}{*}{ 血中 m.f. 隄性犬 } & \multirow{2}{*}{132} & $\%$ & & 34.1 & 5.9 & 7.8 & 31.1 & 21.1 & 0.52 \\
\hline & & $\mathrm{E} / \mathrm{d} \mathrm{I}$ & 7.53 & 2.57 & 0.44 & 0.59 & 2.34 & 1.59 & \\
\hline
\end{tabular}

表 2 犬系状虫症に括ける犬血清蛋白像（平均值士標準偏差）

\begin{tabular}{|c|c|c|c|c|c|c|c|c|c|c|}
\hline & & \multicolumn{2}{|c|}{ 例数 } & $\begin{array}{l}\text { 総蛋白崐 } \\
\mathrm{g} / \mathrm{d} 1\end{array}$ & Albumin & $\begin{array}{l}\text { 白 } \\
a_{1}\end{array}$ & $\begin{array}{l}\text { ग } \\
\alpha_{2}\end{array}$ & \multicolumn{2}{|c|}{$\begin{array}{l}\text { 莌 檤 \% } \\
\text { Globulin }\end{array}$} & $A / G$ \\
\hline 妙 & 照 & 47 & 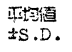 & $\begin{array}{l}6.8 \\
0.62\end{array}$ & 48.1 & $\begin{array}{l}7.5 \\
2.23\end{array}$ & $\begin{array}{l}8.6 \\
2.29\end{array}$ & $\begin{array}{c}22.3 \\
4.06\end{array}$ & $\begin{array}{c}13.5 \\
4.67\end{array}$ & $\begin{array}{l}0.94 \\
0.23\end{array}$ \\
\hline 霉严 & 症 & 23 & 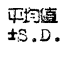 & $\begin{array}{l}7.42 \\
1.60\end{array}$ & $\begin{array}{l}24.5 \\
5.09\end{array}$ & $\begin{array}{l}4.5 \\
2.10\end{array}$ & $\begin{array}{l}4.9 \\
3.00\end{array}$ & $\begin{array}{l}33.6 \\
6.26\end{array}$ & $\begin{array}{r}32.5 \\
7.70\end{array}$ & $\begin{array}{l}0.32 \\
0.11\end{array}$ \\
\hline 軦 & 症 & 27 & 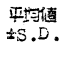 & $\begin{array}{l}7.70 \\
0.68\end{array}$ & $\begin{array}{c}32.9 \\
5.25\end{array}$ & $\begin{array}{l}6.0 \\
2.22\end{array}$ & $\begin{array}{l}7 \cdot 7 \\
4 \cdot 72\end{array}$ & $\begin{array}{l}32.4 \\
6.15\end{array}$ & $\begin{array}{l}21.0 \\
5.72\end{array}$ & $\begin{array}{l}0.49 \\
0.12\end{array}$ \\
\hline 末 & 泟 & 82 & $\begin{array}{l}\text {. 平场価 } \\
\pm S . D .\end{array}$ & $\begin{array}{l}7.50 \\
0.70\end{array}$ & 37.2 & $\begin{array}{l}6.2 \\
1.69\end{array}$ & $\begin{array}{l}8.6 \\
2.72\end{array}$ & $\begin{array}{c}30.0 \\
6.04\end{array}$ & $\begin{array}{r}18.0 \\
5.34\end{array}$ & $\begin{array}{l}0.59 \\
0.19\end{array}$ \\
\hline
\end{tabular}

図 1 犬系状虫症に和ける血清蛋白像

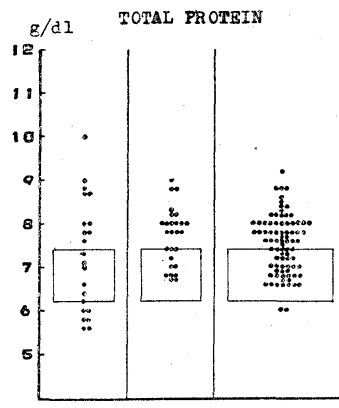

ALPFA I GLOBULIM
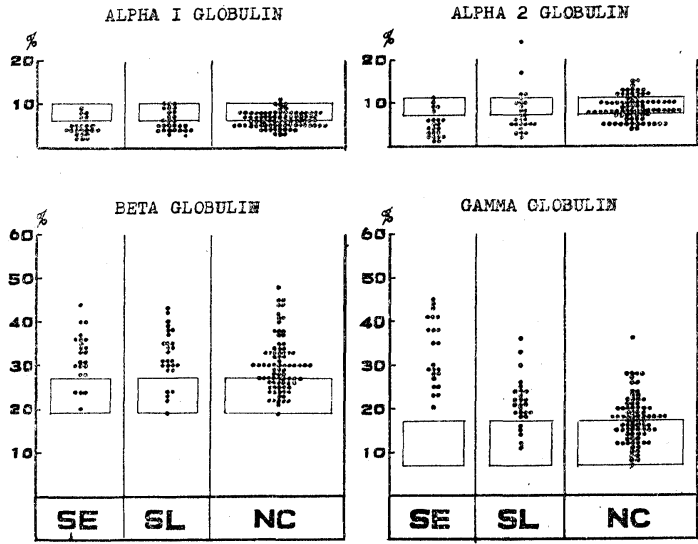

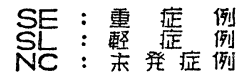

\section{3. 腹水蛋白像}

犬糸状虫症では長期間にわたる循環障害が攀血肝より 肝硬变を招来し, 門脈系の高度の禁血から腹水を発する に至る。一般に腹水発生の要因は種々あるが，決して単 一のものでなく幾つもの要因が関連しあって作用する 3). しかして炎症性滲出液は，局所毛細管透過性の增大 が炎症過程の強さに支配されるために非炎症性の浮腫液 や沪出液に比して蛋白含量が相詨的に高いといわれてい る.ささらに沪出液群に属する肝硬変症の腹水は血漿の性 状を反映するものの総蛋白 (TP) 量は遙かに低く, 一方 渗出液蛋白は沪出液よりもすべての点で血漿蛋白に近似 するといわれ12)，RovERST ら (1958)24)は癌患者腹水の alb 分履透過度が肝硬変患者腹水との鑑別上最も有用で あるとしている．これに対して葛谷ら (1952) 28) は沪出 液と滲出液との蛋白分屑に差はないといい，高橋 (1955) 26) も原因の異なる腹水でも一般に末梢血液の蛋白像によ く類似した蛋白像を示すことを実験的に認めている.

いずれにせよ血清蛋白質は組織蛋白と動的平衡にあ り，したがって血清蛋白のみならず組織液, 浮腫液の動 態を知ることによって生体蛋白代謝の異常，ひいては炎 症の過程をより明確に推測できると思う。そこで典型的 な腹水貯溜を認めた 8 症例と, さらに癌性腹膜炎犬 3 症 例の腹水蛋白像を観察して比較検討した.

すなわち，表 4 にみるごとく，犬糸状虫症の腹水蛋白 像は血清蛋白に比して TP 量は遙かに低值を示し，一方

日獣会誌 15 (1962) 
表 3 血清 複合蛋白像（症例平均）

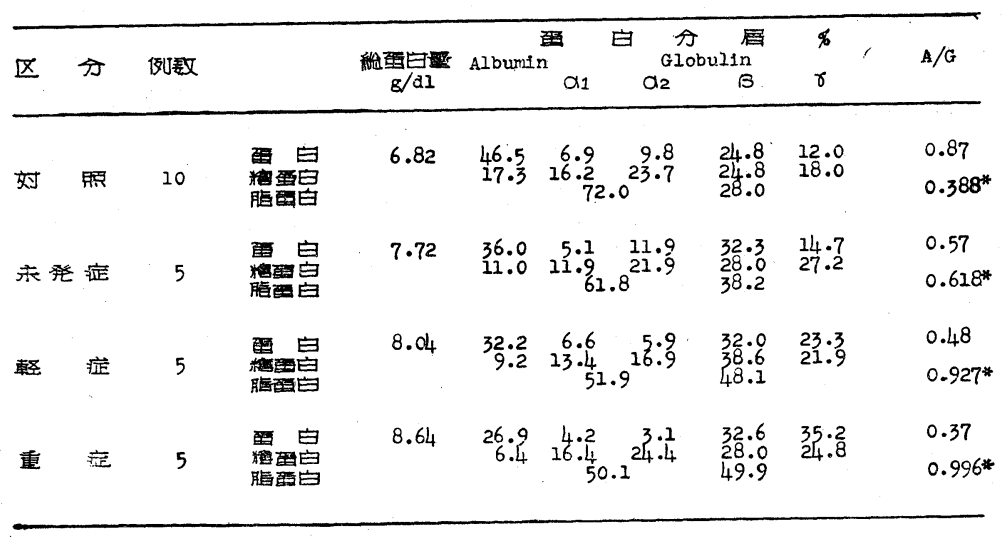

$* \beta / \alpha$ 脂蛋白比

表 4 腹 水蛋白像（症例平均）

\begin{tabular}{|c|c|c|c|c|c|c|c|c|c|c|}
\hline \multirow{3}{*}{\multicolumn{2}{|c|}{ 渡膜次 }} & \multirow{3}{*}{3} & 血 & 5.77 & 35.1 & 5.2 & 13.6 & 24.3 & 21.8 & 0.54 \\
\hline & & & 腹 水 & 3.90 & 39.0 & 4.9 & 12.6 & 27.1 & 16.7 & 0.64 \\
\hline & & & 䡵迵比 & & 1.11 & 0.94 & 0.92 & 1.12 & 0.77 & 1.185 \\
\hline \multirow{3}{*}{\multicolumn{2}{|c|}{ 系沐里应 }} & \multirow{3}{*}{8} & 血 潧 & 7.64 & 23.3 & 4.5 & 4.6 & 34.5 & 33.1 & 0.30 \\
\hline & & & 㬴 $\pi$ & 2.90 & 27.6 & 5.1 & 7.5 & 30.8 & 29.0 & 0.38 \\
\hline & & & 运诚比 & & 1.18 & 1.13 & 1.63 & 0.89 & 0.88 & 1.267 \\
\hline
\end{tabular}

ってもちろん程度の差はあるものの 一般に低 alb, 高glob 状態がみられ る.

そこで，普遍的な犬寄生虫病の血 清蛋白像を観察した結果，図 $2 ， 3$ および表 6 に示す成績が得られた。 犬回虫寄生例は生後 1〜4 力月の仔 犬10例であるが，TP 量に若干低值 を示与傾向を見る以外蛋白分画には 異常は認められない，鞭虫寄生例は いずれも成犬で，いわゆる無症状の .996*，ものには変動なく, 発症例では alb の減少と glob 各分屑の増加の傾向 があり，殊に慢性経過例に $\gamma-$-glob の増加を認めた。 また, 条虫寄生例 は例数の少ない憾みがあるが，一般 に著変を認めなかった。一方，鈎虫 寄生犬では重症例に alb の著減と $\alpha_{2}-, \beta-, \gamma$-glob 各分屑の増加が見 られ，殊に幼若犬に顕著であるが， いわゆる保有犬では対照に比して著 変を示していない，日本住血吸虫感 染犬は実験例で，感染後 50〜60 日 目の急性症では $\alpha_{2}$-glob の増大がと くに顕著であり，また，100～200日 目の慢性症では肝障害を反映して

alb分屑比は若干高く, したがって透過比は 1 より大であ った．癌性腹膜炎蛋白像でも，TP 量が比較的血清蛋白 のそれに近值する以外は蛋白分画, 透過比は犬糸状虫症 腹水の場合とほぼ同じ傾向を呈し大差を認めなかった。

透過度については, 表 5 に示すように腹膜炎腹水で は, TP は全例 0.5 以上, alb に执いても 0.585 以上で かなりの高值を示した. これに対して犬系状虫症の腹水 では, 症状, 腹水貯溜後の経過, 穿刺回数の多寡, 血液 混入や溷濁の有無などによって著るしい相異が認められ た。一般に比較的新鮮な症例（症例 $1,5,7,8$ ) の腹水は 透明かつ血球の混入などが少なく, TP 量も低值を示し ており，透過度も TP で $0.2 \sim 0.3$, albは0.236〜0.476 といずれも 0.5 以下であるが，腹水貯溜後経過が長く渦 去に幾度も穿刺したことのある症例 $(2,3,4,6)$ の腹水 は, 血球の混入も多く, TP 量の増加が認められた。 そ して一般に血清 TP 量も低く, したがって透過度は, TP で $0.437,0.467,0.448,0.607$, albでも $0.480 \sim 0.729$ と高く, 癌性腹膜炎腹水蛋白類似の所見が得られた。

\section{4）主要寄生虫疾患の血清蛋白像}

諸種の病的状態において血清蛋白質は病的機転を反映 して変動を示し, 寄生虫疾患でも, 疾患により症状によ alb の減少と $\beta-\gamma-$ glob の増大が著明に認められる.

したがって犬系状虫奇生犬の血清蛋白像は非特異的な もので慢性肝障害を反映しているといえるが，未発症状 態に限定寸る限りでは, 鉤虫, 鞭虫, 条虫など腸内寄生 虫感染時に比して $\beta-\gamma-$ - lob の增加を示すものが多く, その点で臨床的意義があると思われる。な牧，混合感染 による血清蛋白への影響は認められなかった(表 7 ).

\section{III 考察}

犬糸状虫寄生犬の血清蛋白像は症状の増悪に伴なって 一般に著明となる動態を示し, 就中腹水貯溜などをみる 重症例では alb 分佰の著減と $\beta-, \gamma-$ glob 分屑の著增が 認められ旰硬変様蛋白像を呈するが，比較的症状の軽い 症例や外見上健康と久られる $\mathrm{mf}$ 陽性未発症犬において は，その動態に著るしい個体差が認められた。一般に $\mathrm{mf}$ 陽性犬では，仮令外見上健康とみられる未発症例で も諸種の所見に異常を呈し，とくに肝機能実験には供用 し得ないことが指摘されてお拈り27)，さらに，便宜上塸床 所見から未発症・発症に区分することに問題があり，当 然発症寸前のもの， あるいは移行期のものなど多岐にわ たる段階のものが含まれて和り，加えて患犬の年令・経 
表 5 , 腹 水 蛋白 像

\begin{tabular}{|c|c|c|c|c|c|c|c|c|c|}
\hline 愚 & 例敖 & & 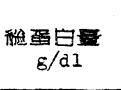 & Album1n & $\begin{array}{c}\theta \\
a_{1}\end{array}$ & ${ }_{d_{2}}{ }_{G}$ & $\begin{array}{c}\text { 展 } \\
\text { Globulin } \\
B\end{array}$ & $\begin{array}{c}g / d I \\
\gamma\end{array}$ & $A / G$ \\
\hline \multirow[t]{3}{*}{ 脢膜炎 } & 1 & $\begin{array}{c}S^{*} \\
A / S \\
A / S\end{array}$ & $\begin{array}{l}6.4 \\
3.5 \\
0.547\end{array}$ & $\begin{array}{l}2.16 \\
1.44 \\
0.505\end{array}$ & $\begin{array}{l}0.35 \\
0.16 \\
0.457\end{array}$ & $\begin{array}{l}1.08 \\
0.64 \\
0.593\end{array}$ & $\begin{array}{l}1.41 \\
0.80 \\
0.557\end{array}$ & $\begin{array}{l}3.12 \\
0.49 \\
0.4 .37\end{array}$ & $\begin{array}{l}0.63 \\
0.69 \\
1.095\end{array}$ \\
\hline & 2 & $\begin{array}{c}S \\
A \\
A / S\end{array}$ & $\begin{array}{l}4.1 \\
4.0 \\
0.731\end{array}$ & $\begin{array}{l}1.45 \\
1.10 \\
0.750\end{array}$ & $\begin{array}{l}0.19 \\
0.13 \\
0.684\end{array}$ & $\begin{array}{l}0.54 \\
0.34 \\
0.629\end{array}$ & $\begin{array}{l}1.03 \\
0.82 \\
0.796\end{array}$ & $\begin{array}{l}0.88 \\
0.61 \\
0.693 .\end{array}$ & $\begin{array}{l}0.55 \\
0.58 \\
1.055\end{array}$ \\
\hline & 3 & $\begin{array}{c}S \\
A \\
A / S\end{array}$ & $\begin{array}{l}6.8 \\
5.2 \\
0.765\end{array}$ & $\begin{array}{l}2.14 \\
2.03 \\
0.948\end{array}$ & $\begin{array}{l}0.39 \\
0.31 \\
0.794\end{array}$ & $\begin{array}{l}0.73 \\
0.42 \\
0.575\end{array}$ & $\begin{array}{l}1.75 \\
1.62 \\
0.926\end{array}$ & $\begin{array}{l}1.80 \\
0.81 \\
0.450\end{array}$ & $\begin{array}{l}0.46 \\
0.64 \\
1.391\end{array}$ \\
\hline 正均 & (3) & $\begin{array}{c}S \\
A \\
A / S\end{array}$ & $\begin{array}{l}5.77 \\
3.90 \\
0.676\end{array}$ & $\begin{array}{l}2.03 \\
1.52 \\
0.0748\end{array}$ & $\begin{array}{l}0.30 \\
0.19 \\
0.633\end{array}$ & $\begin{array}{l}0.78 \\
0.49 \\
0.628\end{array}$ & $\begin{array}{l}1.40 \\
1.06 \\
0.757\end{array}$ & $\begin{array}{l}1.26 \\
0.65 \\
0.516\end{array}$ & $\begin{array}{l}0.54 \\
0.54 \\
1.135\end{array}$ \\
\hline \multirow[t]{8}{*}{ 系状虫旋 } & I & $\begin{array}{c}\mathrm{S} \\
\mathrm{A} / \mathrm{S}\end{array}$ & $\begin{array}{c}12.0 \\
3.8 \\
0.326\end{array}$ & $\begin{array}{l}2.12 \\
1.01 \\
0.476\end{array}$ & $\begin{array}{l}0.28 \\
0.21 \\
0.750\end{array}$ & $\begin{array}{l}0.24 \\
0.14 \\
1.708\end{array}$ & $\begin{array}{l}5.94 \\
1.45 \\
0.24 .4\end{array}$ & $\begin{array}{l}3.42 \\
0.72 \\
0.210\end{array}$ & $\begin{array}{l}0.22 \\
0.36 \\
1.536\end{array}$ \\
\hline & 2 & $\underset{A}{S}$ & $\begin{array}{l}\frac{5.6}{3} \cdot \frac{1}{3} \\
0.607\end{array}$ & $\begin{array}{l}1.77 \\
1.09 \\
0.729\end{array}$ & $\begin{array}{l}0.4 .7 \\
0.24 \\
0.511\end{array}$ & $\begin{array}{l}0.34 \\
0.25 \\
0.735\end{array}$ & $\begin{array}{l}1.92 \\
0.98 \\
0.510\end{array}$ & $\begin{array}{l}1.10 \\
0.64 \\
0.581\end{array}$ & $\begin{array}{l}0.166 \\
0.61 \\
1.326\end{array}$ \\
\hline & 3 & $\begin{array}{c}S \\
A \\
A / S\end{array}$ & $\begin{array}{l}\frac{6.4}{2.4} \\
2.0 .437 \\
0.437\end{array}$ & $\begin{array}{l}1.47 \\
0.72 \\
0.510\end{array}$ & $\begin{array}{l}0.16 \\
0.06 \\
0.375\end{array}$ & $\begin{array}{l}0.19 \\
0.08 \\
0.421\end{array}$ & $\begin{array}{l}2.94 \\
1.23 \\
0.418\end{array}$ & $\begin{array}{l}1.70 \\
0.71 \\
0.417\end{array}$ & $\begin{array}{l}0.28 \\
0.35 \\
1.250\end{array}$ \\
\hline & 4 & $\begin{array}{c}S \\
A \\
A / S\end{array}$ & $\begin{array}{l}5.8 \\
2.6 \\
0.448 \\
0.44\end{array}$ & $\begin{array}{l}1.05 \\
0.50 \\
0.571\end{array}$ & $\begin{array}{l}0.12 \\
0.05 \\
0.416\end{array}$ & $\begin{array}{l}0.07 \\
0.05 \\
0.714\end{array}$ & $\begin{array}{l}2.32 \\
0.85 \\
0.366\end{array}$ & $\begin{array}{l}2.23 \\
1.05 \\
0.470\end{array}$ & $\begin{array}{l}0.22 \\
0.30 \\
1.365\end{array}$ \\
\hline & 5 & $\begin{array}{c}\mathrm{S} \\
\mathrm{A} \\
\mathrm{A} / \mathrm{S}\end{array}$ & $\begin{array}{l}8.2 \\
2.05 \\
0.54 .2\end{array}$ & $\begin{array}{l}1.21 \\
0.58 \\
0.479\end{array}$ & $\begin{array}{l}0.44 \\
0.23 \\
0.523\end{array}$ & $\begin{array}{l}0.68 \\
0.30 \\
0.4 .54\end{array}$ & $\begin{array}{l}2.96 \\
1.09 \\
0.360\end{array}$ & $\begin{array}{l}2.92 \\
0.64 \\
0.219\end{array}$ & $\begin{array}{l}0.17 \\
0.26 \\
1.529\end{array}$ \\
\hline & 6 & $\begin{array}{c}S \\
A \\
A / S\end{array}$ & $\begin{array}{l}6.0 \\
2.8 \\
0.467\end{array}$ & $\begin{array}{l}3.04 \\
0.50 \\
0.480\end{array}$ & $\begin{array}{l}0.26 \\
0.11 \\
0.423\end{array}$ & $\begin{array}{l}0.40 \\
0.33 \\
0.825\end{array}$ & $\begin{array}{l}2.20 \\
1.01 \\
0.455\end{array}$ & $\begin{array}{l}2.10 \\
0.87 \\
0.414\end{array}$ & $\begin{array}{l}0.21 \\
0.22 \\
1.047\end{array}$ \\
\hline & 7 & $\begin{array}{c}S \\
A \\
A / S\end{array}$ & $\begin{array}{l}8.8 \\
2.41 \\
0.273\end{array}$ & $\begin{array}{l}3.35 \\
0.96 \\
0.236\end{array}$ & $\begin{array}{l}0.24 \\
0.06 \\
0.250\end{array}$ & $\begin{array}{l}0.09 \\
0.07 \\
0.778\end{array}$ & $\begin{array}{l}0.80 \\
0.19 \\
0.237\end{array}$ & $\begin{array}{l}4.32 \\
1.12 \\
0.259\end{array}$ & $\begin{array}{l}0.61 \\
0.67 \\
1.098\end{array}$ \\
\hline & 8 & $\underset{A}{S}$ & $\begin{array}{l}8.3 \\
2.5 \\
0.513\end{array}$ & $\begin{array}{l}2.22 \\
0.75 \\
0.738\end{array}$ & $\begin{array}{l}0.66 \\
0.23 \\
0.348\end{array}$ & $\begin{array}{l}0.75 \\
0.17 \\
0.227\end{array}$ & $\begin{array}{l}2.0 h \\
0.72 \\
0.353\end{array}$ & $\begin{array}{l}2.61 \\
0.73 \\
0.279\end{array}$ & $\begin{array}{l}0.40 \\
0.41 \\
1.025\end{array}$ \\
\hline 平均 & (8) & $\begin{array}{c}\mathrm{S} \\
\mathrm{A} \\
\mathrm{A} / \mathrm{S}\end{array}$ & $\begin{array}{l}7.64 \\
2.90 \\
0.379\end{array}$ & $\begin{array}{l}1.78 \\
0.80 \\
0.1449\end{array}$ & $\begin{array}{l}0.34 \\
0.15 \\
0.444\end{array}$ & $\begin{array}{l}0.35 \\
0.22 \\
0.611\end{array}$ & $\begin{array}{l}2.63 \\
0.89 \\
0.333\end{array}$ & $\begin{array}{l}2.53 \\
0.64 \\
0.332\end{array}$ & $\begin{array}{l}0.30 \\
0.38 \\
1.267\end{array}$ \\
\hline
\end{tabular}

病期間・病歴あるいは抵抗の問題など諸種の要因が重な って症例による著るしい相異を招いたとも考えられる.

血清蛋白像は健常時でも年令による相異を示すが, $\mathrm{mf}$ 陽性犬に括いても一般に年令のすすむにともなって alb の減少と r-glob の増加が顕著となる傾向がうかがわれ るものの，前述したごとく症状その他を反映して個体差 がみられ, 高令なもの程少の傾向が著るしく認められ, したがってもちろん有意とはいえなかった。

北村ら(1954)13)は人のフィラリア症において，末杪血 中 $\mathrm{mf}$ 数と $\gamma$-glob 量との間には量的関係はほとんど認 められないとして敊り, 一方, 症状との関係でも一般に 成虫寄生数の多いもの程発症率の高い傾向があるが，末 梢血中 $\mathrm{mf}$ 数之成虫数ならびに発症率との間に一定の関 係はないと考えられて扮り14), 著者の観察でも同様な所 見を認めることができた.

犬系状虫症では貧血が認められ, 重症例程高令犬程高 度かつ高率に貧血を呈し, alb 量の減少と $\gamma$-glob 量の 增加が顕著となる傾向を認めるが, 症状と貧血は必らず
しも一致しないようで，未発症 $\mathrm{mf}$ 陽性犬でも貧血を呈するものがあ り，これらの例に执いては貧血と血 清蛋白像との間に明確な量的関係は みられなかった。

一般に 2 次的貧血症に和ける血清 蛋白の動態は, 貧血を惹起せしめて いる基礎的疾患に制約される泳動像 を示し，貧血に特哄的なものではな い.しかして, 病的血清蛋白像は非 特異的であって, 炎症や障害の程度 を反映する点に意義があるので，未 発症犬に打忷る貧血や血中 $\mathrm{mf}$ 数と 血清蛋白像との関係に明確な所見が 得られなかったことは, 畢竟これら の所見が症状と密接な関係を有して いないことに帰せられると思う。

各種疾患に打けるリポ蛋白拈よび 糖蛋白各分画の意義は沪紙電気泳動 法によって検討されて抢り4,17,23), 五味淵 (1956)5) は血清蛋白・糖蛋 白・リポ蛋白が疾患により症状によ ってそれぞれ特徵を示し, 臨床上極 めて有意義であり, 血清蛋白分屑の みからの観察とは別個の立場から血 清蛋白, ひいては疾病の把握が可能 であると指摘した. しかして，リポ 蛋白の動態として 4 塩化炭素中毒家 鬼に $\alpha$ - Lp の減少が認められており 20), 肝疾患でも $\beta / \alpha \operatorname{Lp}$ 比の上昇が あり, とくに肝硬変において著るしいという. 犬糸状虫 重症例に括ける $\beta-\mathrm{Lp}$ の増大， $\beta / \alpha \mathrm{Lp}$ 比の上昇は明ら かに肝障害, 就中肝硬変を反映したものと推測できるけ れぞも, 例数に乏しく症例による変動の差が著るしいこ とを軽症・未発症例に認めたので, その臨床的意義の解 明はリポ蛋白の生化学的問題の追究とともに今後の研究 に俟たねばならないと考える。

犬系状虫症に拈いては高度の肝障害から腹水の貯溜を みるに至るが, その腹水蛋白像と癌性腹膜炎腹水蛋白像 と比較してみると, 一般に前者では TP 量低く, alb 透 過度も低值を示すものが認められる。しかしながら，患 犬の症状や腹水の性状, 寸なわら経過の長短, 血液混入 の有無あるいは多寡, 穿刺回数などによって種々の相異 が認められ, 陳旧症例, 血液混入, 穿刺回数の頻繁な腹 水では癌性腹膜炎腹水類似の蛋白像を示した。 このこと は, 心筋障害あるいは合併症のない肝硬変などによって 招来される胸膜・腹膜沪出液は，一般に低蛋白濃度を示 すが，その沪出が長く継続するときは水分の再吸収によ

日獣会誌 15 (1962) 


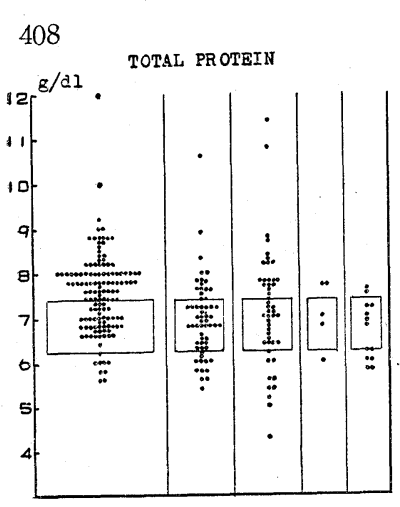

家畜血清蛋白に関する沪紙電気泳動学的研究

↔図 2 諸種寄生虫疾患に怙ける血清蛋白像（成犬） 考学られている11).
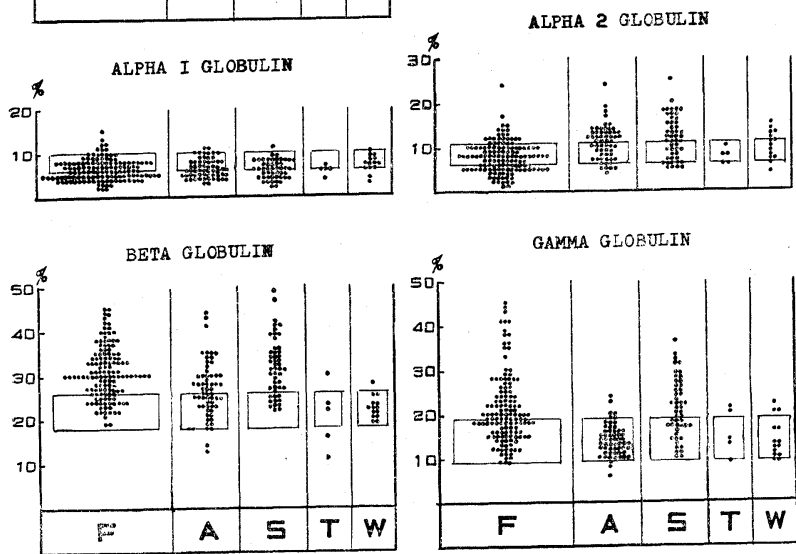

F 犬系狀虫症

A 鉤田症 5 日本住血吸出症

T需症

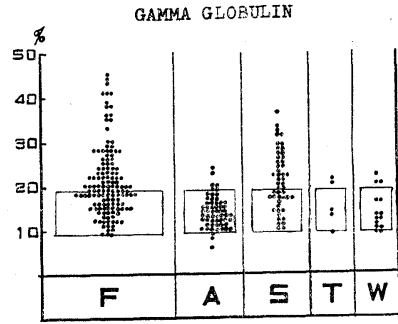

F W 蹧里症 $\square$ 正常预团 って蛋白濃度が高くなり，遂には真の滲出液と同じ蛋白 濃度に達すること, さらにこのような状態では血管透過 性が增大して血清蛋白像と類似の像を呈するに至るこ と，あるいは血液混入・反覆穿刺によって蛋白分画が漸 次血清のそれに近づくことなどによっても十分納得され 得るものである.このように沪出現象継続の期間が腹水 蛋白の動態に大きな影響を与えることから，犬系状虫症 腹水蛋白像の観察に当っては十分このことを念頭に拈い て行なわねばならない。

また，浮腫の発現は膠質滲透圧の低下と関係があり， 膠質滲透圧の維持と alb とが密接な関係を有するところ から, 浮腫の発現を低 alb 血の水準と関係づけようとす る試みがなされているが，腹水の発生には多くの要因が 関与して括り, 肝硬変症に郝将る血漿 alb の低下は腹水 の有無に影響されない許りでなく, 高橋 (1955) 26 )はalb 量の減少が腹水発生の必要条件ではないことを指摘して いる. 犬糸状虫症腹水貯溜犬でも 8 例中 7 例に著明な alb 量の低下を認めたが，1例において見掛け上の值で はあるが必らずしも alb 量の著減を示すとは限らないこ とを観察した。

肝臓が血清 alb の主要産生場所であるだけでなく，一 部 glob の生成ならびに血清蛋白分画の調整にも参与し ているところから, 多くの肝疾患に血清 alb の減少, glob の増加が認められ, さらに glob 分画の変動は肝実
質障害の程度ならびにその推移とよく一致すると

平山ら(1958)8) は血清蛋白像と肝藏組織像との 関係について，血清 alb および $\alpha$-glob は肝細胞 の機能を反映し, alb は肝細胞障害とともに減少 し， $\alpha$-glob は中等度までの障害で増加し強度の 障害では減少することを認め, また $r$-glob も肝 細胞の障害で増加し肝蔵のすべての形態学的変化 を強く反映するといっている，さらに，r-globの 増加は炎症性のものでも変性性のものでも広汎な 肝障害を反映して早期に出現し3)，䍚血肝，㮾血 性肝硬変の場合に，それ以外によっては臨木的に 理解できない時期に肝䍚血の結果とみられる血清 蛋白変化があり得ることは注意すべきであるとい われている9)。このように肝疾患に拈ける血清蛋 白分画の変動は, それら疾患の鑑別診断, 予後の 判定ならびに治療方針の樹立に対し有力な資料と なり得ることが認められている10). 事実, 犬系状 虫症にみられる血清蛋白の動態は, 発症犬とくに 症状が悪化し障害の十分進行した症例では，他の

図 3 諸種寄生虫疾患に拉ける血清蛋白像(幼若犬)
TOTAL PROTEIN

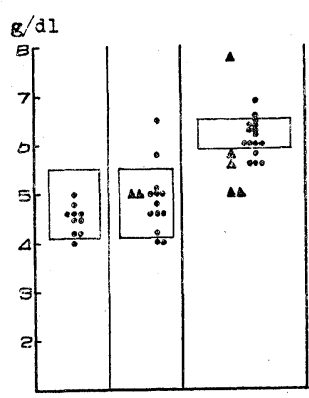

ALPHA I GLOBULIN

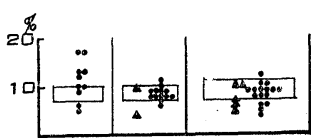$$
\%
$$

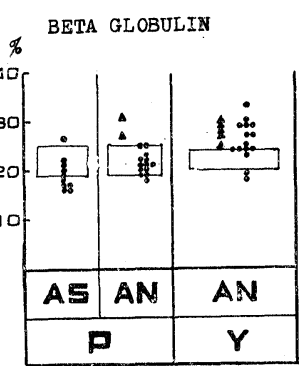

As 回虫症 AN 钧虫症
ALBUMIN

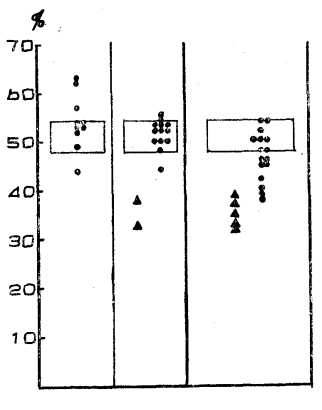

ALPHA 2 GLOBULIN
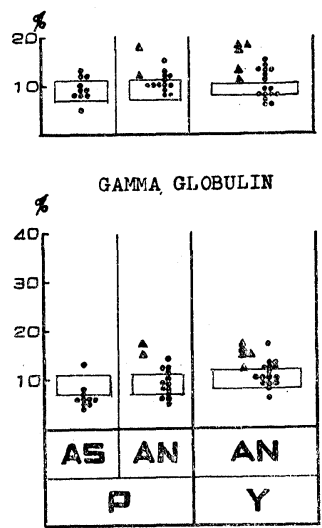

2 巳 4月仔大、重症例 5 B 月幼犬 $\square$ 正常範团
日獣会誌 15 (1962) 
表 6 諸種寄生虫疾患に打ける血清蛋白像（症例平均）

に著変を示すものが多数観察された

\begin{tabular}{|c|c|c|c|c|c|c|c|c|c|c|c|c|}
\hline 疾 & 鲅 & 年令 & & 例教 & & 総霉日量 & Albumin & & 白 & 分 & 層 \% & $A / G$ \\
\hline & & & & & & & & $a_{1}$ & $a_{2}$ & $B$ & & \\
\hline 詨 & 照 & $2-41$ & 月 & 32 & $\begin{array}{l}m \\
s\end{array}$ & $\begin{array}{l}4.8 \\
0.65\end{array}$ & $\begin{array}{c}50.8 \\
3 . d_{4}\end{array}$ & $\begin{array}{l}8.9 \\
1.37\end{array}$ & $\begin{array}{l}9.2 \\
1.89\end{array}$ & $\begin{array}{r}22.5 \\
2.12\end{array}$ & $\begin{array}{l}8.8 \\
1.59\end{array}$ & $\begin{array}{l}1.03 \\
0.23\end{array}$ \\
\hline 回虫: & 症 & $1-4 \mathrm{~F}$ & 月 & 10 & $\stackrel{m}{\mathbf{s}}$ & $\begin{array}{l}4.50 \\
0.30\end{array}$ & $\begin{array}{l}54.0 \\
5.56\end{array}$ & ${ }_{3.77}^{11.1}$ & $\begin{array}{l}9.3 \\
2.79\end{array}$ & $\begin{array}{l}19.1 \\
2.95\end{array}$ & $\begin{array}{l}6.5 \\
2.59\end{array}$ & $\begin{array}{l}1.18 \\
0.27\end{array}$ \\
\hline 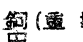 & 症) & & 月 & 2 & $\mathrm{~m}$ & 5.00 & 35.0 & 7.0 & 14.5 & 28.2 & 15.3 & 0.54 \\
\hline 焉 (综有 & (5) & $2-41$ & & 13 & $\stackrel{\mathrm{m}}{\mathrm{s}}$ & $\begin{array}{l}4.86 \\
0.54\end{array}$ & $\begin{array}{l}51.0 \\
2.66\end{array}$ & $\begin{array}{l}8.3 \\
1.35\end{array}$ & $\begin{array}{c}10.6 \\
2.08\end{array}$ & ${ }_{1.85}^{21.1}$ & $\begin{array}{l}9.0 \\
2.71\end{array}$ & $\begin{array}{l}1.04 \\
0.11\end{array}$ \\
\hline 部 & 照 & $5-8$ & & 26 & $\stackrel{m}{s}$ & $\begin{array}{l}6.2 \\
0.33\end{array}$ & $\begin{array}{c}50.7 \\
3.90\end{array}$ & 9.1 & $\begin{array}{l}8.5 \\
0.80\end{array}$ & 21.6 & $\begin{array}{l}10.1 \\
1.83\end{array}$ & $\begin{array}{l}1.03 \\
0.08\end{array}$ \\
\hline $\begin{array}{l}\text { 銁 (雷 } \\
\text { 虫 }\end{array}$ & 症) & $5-8$ & & 5 & $\underset{s}{m}$ & $\begin{array}{l}5.84 \\
1.15\end{array}$ & 35.1 & $\begin{array}{l}7 \cdot 3 \\
2 \cdot 86\end{array}$ & $\begin{array}{r}15.2 \\
3.24\end{array}$ & $\begin{array}{l}27.6 \\
1.90\end{array}$ & $\begin{array}{l}14.8 \\
2.00\end{array}$ & $\begin{array}{l}0.54 \\
0.07\end{array}$ \\
\hline 症（渭有） & & $5-8$ & & 16 & $\underset{s}{m}$ & $\begin{array}{l}6.14 \\
0.38\end{array}$ & $\begin{array}{l}46.5 \\
5.04\end{array}$ & $\begin{array}{l}8.0 \\
2.05\end{array}$ & $\begin{array}{r}10.0 \\
3.00\end{array}$ & $\begin{array}{l}25.0 \\
4.63\end{array}$ & $\begin{array}{r}10.5 \\
2.50\end{array}$ & $\begin{array}{l}0.87 \\
0.19\end{array}$ \\
\hline 対 & 照 & $1-4=$ & & 47 & $\begin{array}{l}\mathrm{m} \\
\mathrm{s}\end{array}$ & $\begin{array}{l}6.8 \\
0.63\end{array}$ & $\frac{48.1}{5.08}$ & $\begin{array}{l}7.5 \\
2.23\end{array}$ & $\begin{array}{l}8.6 \\
2.29\end{array}$ & $\begin{array}{l}22.3 \\
4.06\end{array}$ & $\begin{array}{l}13.5 \\
4.67\end{array}$ & $\begin{array}{l}0.94 \\
0.23\end{array}$ \\
\hline 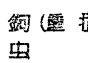 & 怔) & 成 & 犬 & 15 & $\begin{array}{l}\mathrm{m} \\
\mathrm{s}\end{array}$ & $\begin{array}{l}7.35 \\
1.26\end{array}$ & $\begin{array}{l}35.0 \\
5.88\end{array}$ & $\begin{array}{l}6.7 \\
2.80\end{array}$ & $\begin{array}{r}12.4 \\
5.12\end{array}$ & 29.6 & $\begin{array}{c}16.3 \\
4.42\end{array}$ & $\begin{array}{l}0.54 \\
0.17\end{array}$ \\
\hline 症 (保不) & & 成 & 犬 & 44 & $\begin{array}{l}\mathrm{m} \\
\mathrm{s}\end{array}$ & $\begin{array}{l}6.80 \\
0.64\end{array}$ & $\begin{array}{l}44.3 \\
5.13\end{array}$ & $\begin{array}{l}6.5 \\
2.02\end{array}$ & $\begin{array}{c}10.3 \\
3.11\end{array}$ & $\begin{array}{l}25.9 \\
4.95\end{array}$ & $\begin{array}{c}13.0 \\
3.93\end{array}$ & $\begin{array}{l}0.80 \\
0.22\end{array}$ \\
\hline 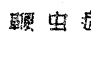 & 症 & 成， & 犬 & 14 & $\underset{s}{m}$ & $\begin{array}{l}6.60 \\
0.62\end{array}$ & $\begin{array}{l}47.5 \\
5.71\end{array}$ & $\begin{array}{l}6.8 \\
1.98\end{array}$ & $\begin{array}{l}9.9 \\
3.22\end{array}$ & $\frac{22.2}{2.39}$ & 13.6 & $\begin{array}{l}0.90 \\
0.23\end{array}$ \\
\hline 浩虫 & 症 & 成， & 犬 & 5 & $\begin{array}{c}\mathrm{m} \\
\mathbf{s}\end{array}$ & $\begin{array}{l}7.04 \\
0.71\end{array}$ & $\begin{array}{l}51.4 \\
10.24\end{array}$ & $\begin{array}{l}5.6 \\
1.12\end{array}$ & $\begin{array}{l}7.4 \\
1.67\end{array}$ & $\begin{array}{c}20.3 \\
7.44\end{array}$ & 15.36 & $\begin{array}{l}1.06 \\
0.44\end{array}$ \\
\hline 早吸(無) & & 成 7 & 犬 & 26 & $\stackrel{m}{s}$ & $\begin{array}{l}7.3 \\
0.56\end{array}$ & $\begin{array}{l}30.2 \\
3.38\end{array}$ & $\begin{array}{l}6.0 \\
0.78\end{array}$ & $\begin{array}{r}14.5 \\
1.81\end{array}$ & $\begin{array}{r}31.4 \\
2.50\end{array}$ & $\begin{array}{c}17.0 \\
1.87\end{array}$ & $\begin{array}{l}0.45 \\
.0 .07\end{array}$ \\
\hline 奮淀 (瀿) & & 成 & ホ & 25 & $\begin{array}{l}\mathrm{m} \\
\mathrm{s}\end{array}$ & $\begin{array}{l}7.0 \\
0.46\end{array}$ & $\begin{array}{c}28.7 \\
2.39\end{array}$ & $\begin{array}{l}5.3 \\
0.98\end{array}$ & $\begin{array}{l}9.3 \\
2.21\end{array}$ & $\begin{array}{c}32.7 \\
3.58\end{array}$ & $\begin{array}{c}24.0 \\
1.88\end{array}$ & $\begin{array}{l}0.40 \\
0.07\end{array}$ \\
\hline 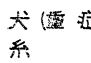 & (i正) & 成 & 犬゙ & 23 & $\underset{s}{m}$ & $\begin{array}{l}7.42 \\
1.60\end{array}$ & $\begin{array}{c}24.5 \\
5.09\end{array}$ & $\begin{array}{l}4.5 \\
2.10\end{array}$ & $\begin{array}{l}4.9 \\
3.00\end{array}$ & $\begin{array}{l}33.6 \\
6.36\end{array}$ & $\begin{array}{c}32.5 \\
7.70\end{array}$ & $\begin{array}{l}0.32 \\
0.11\end{array}$ \\
\hline 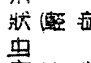 & & 成 & ホ & 27 & $\underset{s}{m}$ & $\begin{array}{l}7.70 \\
0.66\end{array}$ & $\begin{array}{c}32.9 \\
5.25\end{array}$ & $\begin{array}{l}6.0 \\
2.22\end{array}$ & $\begin{array}{l}7.7 \\
4.72\end{array}$ & $\begin{array}{c}32.4 \\
6.15\end{array}$ & $\begin{array}{c}21.0 \\
5.72\end{array}$ & $\begin{array}{l}0.49 \\
0.12\end{array}$ \\
\hline 症 (本発拍 & & 成， & 犬 & 82 & $\mathrm{~m}$ & $\begin{array}{l}7.50 \\
0.70\end{array}$ & $\begin{array}{c}37.2 \\
6.50\end{array}$ & $\begin{array}{l}6.2 \\
1.69\end{array}$ & $\begin{array}{l}8.6 \\
2.72\end{array}$ & $\begin{array}{c}30.0 \\
6.04\end{array}$ & $\begin{array}{c}18.0 \\
5.34\end{array}$ & $\begin{array}{l}0.59 \\
0.19\end{array}$ \\
\hline
\end{tabular}

$\mathrm{m}$ 平均值 $\mathrm{s}$ 標準偏差

表 7 混合感染犬の血清蛋白像（無症状保有犬 平均士標準偏差）

\begin{tabular}{|c|c|c|c|c|c|c|c|c|c|c|}
\hline 威 & 浱 & 部数 & & 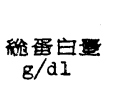 & $\begin{array}{r}\text { 垔 } \\
\text { Albumin }\end{array}$ & $\begin{array}{l}\text { 白 } \\
\alpha_{1}\end{array}$ & $\begin{array}{l}\text { 今 } \\
\text { Globu } \\
\alpha_{2}\end{array}$ & $\begin{array}{c}\operatorname{lin}_{\beta} \\
B\end{array}$ & $\gamma$ & $A / G$ \\
\hline 奶 & 照 & 7 & $\mathrm{~m}_{\mathrm{s}}^{*}$ & $\begin{array}{l}6.40 \\
0.49\end{array}$ & $\begin{array}{c}49.0 \\
1.28\end{array}$ & $\begin{array}{l}8.0 \\
2.03\end{array}$ & $\begin{array}{l}8.7 \\
2.23\end{array}$ & $\begin{array}{r}23.8 \\
3.03\end{array}$ & $\begin{array}{c}10.4 \\
1.45\end{array}$ & $\begin{array}{l}0.96 \\
0.04\end{array}$ \\
\hline 鋾 & 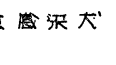 & 15 & ${ }_{\mathrm{s}}^{\mathrm{m}}$ & $\begin{array}{l}6.50 \\
0.58\end{array}$ & 44.90 & $\begin{array}{l}5.8 \\
2.05\end{array}$ & $\begin{array}{c}13.0 \\
2.27\end{array}$ & $\begin{array}{r}25.7 \\
4.00\end{array}$ & $\begin{array}{r}12.6 \\
2.40\end{array}$ & $\begin{array}{l}0.82 \\
0.11\end{array}$ \\
\hline 鈎虫 & 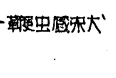 & 11 & $\underset{s}{m}$ & $\begin{array}{l}7.30 \\
0.55\end{array}$ & $\begin{array}{l}42.0 \\
3.77\end{array}$ & $\begin{array}{l}6.44 \\
2.42\end{array}$ & $\begin{array}{c}10.5 \\
3.11\end{array}$ & $\begin{array}{r}28.0 \\
4.10\end{array}$ & $\begin{array}{r}13.1 \\
2.96\end{array}$ & $\begin{array}{l}0.72 \\
0.12\end{array}$ \\
\hline 系狀 & 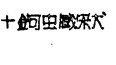 & 10 & $\frac{m}{s}$ & $\begin{array}{l}7.55 \\
0.70\end{array}$ & $\begin{array}{c}35.2 \\
9.75\end{array}$ & $\begin{array}{l}5.4 \\
1.83\end{array}$ & $\begin{array}{l}8.5 \\
3.11\end{array}$ & $\begin{array}{c}29.8 \\
6.51\end{array}$ & $\frac{21.1}{8.73}$ & $\begin{array}{l}0.54 \\
0.21\end{array}$ \\
\hline 系 光 & 虫威吥大” & 6 & $\underset{s}{m}$ & $\begin{array}{l}7.82 \\
0.62\end{array}$ & $\begin{aligned} 33.3 \\
7.43\end{aligned}$ & $\begin{array}{l}6.5 \\
2.86\end{array}$ & $\begin{array}{l}6.8 \\
2.15\end{array}$ & $\begin{array}{r}32.6 \\
3.03\end{array}$ & $\begin{array}{r}20.8 \\
5.50\end{array}$ & $\begin{array}{l}0.50 \\
0.19\end{array}$ \\
\hline
\end{tabular}

ことは，血清蛋白像と肝障害との関 係ならびに本症の侵襲過程, 発症機 転より考えて臨床上参考とすべき点 が多いと思う。したがって，本症に 和ける血清蛋白の動態から宿主生体 の症状，とくに肝障害の程度を十分 推測し得ると考兄られるが，血清蛋 白所見のみだけでなく，血清複合㔻 白分画や腹水蛋白の動態，さらには 血液検查や肝機能検查など多角的か つ総合的に検討することによって， より確実に宿主生体の反応状態，ひ いては症状・障害の程度を把握する ことが期待できる。

一方，犬系状虫症は直接あるいは 間接に心障害をともない，血行障害 や心代償不全の状態が肝の蛋白代謝 に影響を和よぼしていることは当然 であり，各種心疾患に执いても代謝 障害時に alb の著減と $\gamma$-glob の増 加が認められて打り15)，秋田ら (19 58)1） は実験的 3 尖弁閉鎖不全犬末 梢血血清蛋白像が著明な TP 量之 alb 量の減少扰よび $\alpha_{2}-, \gamma-$ glob 量 の増加を示し, さらに腹水貯溜例で は全例 $2.3 \mathrm{~g} / \mathrm{dl}$ 以下という著明な alb 濃度の減少を認めたことを報告 している. 臨床例についての観察で あり, 心障害の程度を明確にし得な かったので, 心障害と血清蛋白所見 との関係については今後の検討に俟 ちたいと思う。

\section{IV 要 約}

犬系状虫症に括ける血清蛋白の動 態を沪紙電気泳動法によって観察 乙, 臨床症状・年令・末梢血液中 $\mathrm{mf}$ 数・負血々の関係を検討すると ともに血清複合蛋白および腹水蛋白 の動態をも観察した.

* $\mathrm{m}$ 平均值 $\mathrm{s}$ 標準偏差

諸種郜床検査所見ともほぼ平行して alb の著減と $\beta-, \gamma-$ glob の著増を示し，障害の程度をかなり明確に反映し たのはもらろんであるが，外見上健康と又える $\mathrm{mf}$ 陽性 未発症犬や臨床所見・諸検査成績に余り著変を認めない 症例, あるいは高令犬などに和いて, albの著減, $\beta-, \gamma$ glob の著增あるいは $\alpha$-glob の増加など血清蛋白分画
その結果， $\mathrm{mf}$ 陽性犬に扮いては一般に alb 分晚の減 少之 $\beta-, \gamma-$ glob 分佰の増大が見られ, もちろ几症例に よって若干の相異があるが発症ならびに症状の増恶とと もにその動態は著明となる傾向を示し，重症例では著る しい alb 量の低下と $\gamma$-glob 量の增大が認められた，複 合蛋白分画に扮いても一般に $\beta-\operatorname{Lp}$ の増加がみられ，さ らに腹水蛋白所見では癌性腹膜炎腹水に比して TP 量低

日獣会誌 15 (1962) 
く，alb 透過度も若干低值を示す傾向を認めることがで きた。

稿を終るに当り，終始ご懇篤なご指導とご校閲を賜つ た大越 伸教授に涑甚の謝意を表しむすとともに実験遂 行上種々ご協力を賜わった内科学教室員各位に深謝しま す。な㸱, 本論文の大要は第67回日本臨床獣医学会（東 京）に打いて発表した。

$$
\text { 交献 }
$$

1) 秋由,馬渡, 大熊 : 生物物理化学, 5, 113 (1958). 2) 荒井，坂岸，野見山：生物物理化学，3，56(1956). 3) Cantarow, A., and Trumper, M.: Clinical Biochemistry, W.B. Sanders Campany, Philaderphial London (1955). 4) FAsoli, A. : Acta. Med. Scand., 145, 233 (1953), (Chem. Abst., 47, 7638). 5) 五味淵：日大医誌, 15, 2350 (1956). 6) GutmanN, A.B. : Adv. Prot. Chem., 4, 155 (1948). 7) 平井, 島尾: 電気泳動法, 共立, 東京 (1955). 8) 平山, 外 : 生物物理化学, $4(3,4), 24$ (1958).9) 藤田：血墏 蛋白の臨床, 文光堂, 東京 (1956). 10) 藤田 : 総合臨 床, 6, 1332 (1957).
11）井上, 市原, 吉川 : 臨床生化学 II, 朝倉, 東京 (1959). 12) 石川 : 生物物理化学, 2, 105 (1955). 13) 北村, 片峰: 寄学誌, 3,13 (1954). 14) 久米, 黒川：日獣会誌, $13,7(1960)$. 15) 前川, 外：生物 物理化学, 5, 170 (1958). 16) 桝屋, 門田, 有馬:日 血会誌, 19,216 (1956). 17) 三上, 外：生物物理化 学, 3, 237 (1956). 18) 三好: 臨床, 5, 729(1952). 19) 永田, 山田:日獣医, 21 (会), 101 (1959). 20) 王子：臨床生理化学シンポジウム 第 1 集, 64 (1957).

21) Polson, A., and Mainerbe, W.D.: Ondersteport J. Vet. Research, 25, 13 (1952). 22) Peтermann, L.M. : The Plasma Proteins II (Edited by Putnam, F.W.), 309, Academic Press Inc. Publishers, New York (1960). 23) Pezold, F.A.: Lipide und Lipopreoteide im Blutplasma, Springerverlag, Berlin (1961). 24) Roverst, A.A., et al., : Gastroenterology, 34, 446 (1958), (生物物理化学, 6, 97 よ り引用). 25）沪紙電気泳動標準操作法小委員会：生 物物理化学, 4, 62 (1958). 26) 高橋: 生物物理化学, 2, 259 (1955). 27) 塚本：日消誌, 51, 349 (1954). 28）葛谷，所司原：日消誌，49(5)，87 (1952).

Clinical Studies on Serum Protein Changes in Canine Filariasis $\mathrm{V}$ (1). Changes in Serum Protein, Serum Compound Protein, and Ascitic Protein

IsAmU TOMODA

(Department of Medicine, Division of Veterinary Science, Faculty of Agriculture, University of Tokyo)

\section{SUMMARY}

Changes in serum protein, serum compound protein, and ascitic protein were investigated in dogs infected with Dirofilaria immitis by using paper electrophoresis.

Changes in serum protein which occurred in a great number of infected dogs consisted of a decrease in albumin and an increase in beta- and gamma-globulin. They usually included an increase in total protein concentration. In the severe case with an accumulation of ascitic fluid, there were a striking rise in gamma-globulin and a significant decrease in albumin. Also there was a tendency for the alpha- and beta-glycoprotein fractions and the beta-lipoprotein fraction to be elevated in many cases. These exhibited a markedly great increase in accordance with the progress of the disease. On the other hand, the protein patterns of the ascitic fluid resembled those of the serum, but the

\section{（419頁より）文献}

1) 中村, 本橋, 岸, 川䆶, 田島：日獣学誌, 22,486 (1960). 2) 藤江, 倉田, 沢田, 信藤：日獣会誌, 14, 196 (1961). 3) Prier, J.E.: J. Amer. Vet. Med. Ass., 137, 577 (1960)。 4) 佐藤 : 獣医界, No. 38, 14 (1957). 5) Baker, J.M., Chappel, C.I. and Dale, albumin composition of the former showed a higher percentage than that of the latter.

In general, no notable changes were observed in the proteins in roundworm, tapeworm, and whipworm carriers which manifested no clinical symptoms of parasitism. Whereas albumin and alpha$2-$, beta-, and gamma-globulin underwent remarkable changes in the severe case of hookworm disease, such changes were not distinctly evidenced in these carriers. On the other hand; remarkable changes were found in many heartworm carriers, which exhibited a protein response similar to that obtained in the chronic form of schistosomiasis.

Therefore, it was presumed that the serum protein pictures in canine filariasis were characteristic not of the specific disease but of the host's reaction to the infection and injury.
D.G. : Canad. J. Comp. Med., 24, 359 (1960). 6) York, C.J. and Burch, G.R.: J. Amer. Vet. Med. Ass., 138, 298 (1961). 7) 一条, 束野, 道下: 獣音 新報, No. 314, 18 (1961). 8) 小林, 大石, 久米: 獣 医界, No. 55, 7 (1960). 9) Piercy, S.E.: Vet.Rec., 73, 944 (1961). 